\title{
Sustainability the remittances received in Puebla and Guerrero, Mexico
}

\section{Sostenibilidad de las remesas recibidas en puebla y Guerrero, Mexico}

\author{
HARO-ZEA, Karla Liliana †** \& CONTRERAS-ALCÁNTARA, Karla \\ Benemérita Universidad Autónoma de Puebla
}

ID $1^{\text {st }}$ Author: Karla Liliana, Haro-Zea / ORC ID: 0000-0002-7257-0673, Researcher ID Thomson: F-2404-2018, CVU CONACYT ID: 375380, SNI CONACYT ID: 68081

ID $1^{\text {st }}$ Coauthor: Karla, Contreras-Alcántara

DOI: $10.35429 / J S R .2020 .17 .6 .32 .43$

Received January 10, 2020; Accepted April 01, 2020

\begin{abstract}
The purpose of this research is to study if there is sustainable development from remittances sent to families in Puebla and Guerrero, Mexico; since remittances represent a fundamental income for families in places with high migratory intensity, hence the importance of carrying out this research. In this research, income from remittances received by families from Puebla and Guerrero was studied, as well as the difference with respect to gender and place of origin. It is an exploratory, descriptive, explanatory and transversal research. The sample was not probabilistic by 50 people in each state, so the sample is a total of 100 people. To collect the data, an instrument was applied to measure the impact of the news received, its use and benefit. The results showed that $33 \%$ of relatives of migrants based in the United States of America managed to start a business based on remittances received in Puebla and Guerrero, and there was a greater entrepreneurial spirit on the part of women. Therefore, it can be said that for Mexican migrants and their families, a route to sustainability is the sending of remittances through investment.
\end{abstract}

Sustainability, Migration, Entrepreneurship

\section{Resumen}

Esta investigación tuvo como propósito estudiar si existe sostenibilidad a partir de las remesas enviadas a familias de Puebla y Guerrero, México; toda vez que las remesas representan un ingreso fundamental para las familias en localidades de alta intensidad migratoria, de ahí la importancia de llevar a cabo esta investigación. En el estudio se consideraron como ingreso las remesas percibidas por familias poblanas y guerrerenses, así como también se analizan las diferencias respecto al género y lugar de origen. Es una investigación de tipo exploratoria, descriptiva, explicativa y transversal. La muestra fue no probabilística por cuotas de 50 personas en cada estado, por lo que la muestra es un total de 100 personas. Para la recolección de los datos se aplicó una encuesta para medir el impacto de las remesas recibidas, su uso y beneficio. Los resultados mostraron que, el $33 \%$ de los familiares de migrantes radicados en Estados Unidos de América logró emprender un negocio a partir de las remesas recibidas en Puebla y Guerrero, existiendo mayor emprendimiento por parte de las mujeres. Por lo que se puede decir que para los migrantes mexicanos y sus familiares, una ruta hacia la sostenibilidad es el envío de remesas vía inversión.

Sostenibilidad, Migración, Emprendimiento

Citation: HARO-ZEA, Karla Liliana \& CONTRERAS-ALCÁNTARA, Karla. Sustainability the remittances received in Puebla and Guerrero, Mexico. Journal of Social Researches. 2020. 6-17: 32-43.

\footnotetext{
* Correspondence to Author (email: kharozea@gmail.com)

$\dagger$ Researcher contributing as first author.
} 


\section{Introduction}

This study carried out an analysis on the economic sustainability of families living in Puebla and Guerrero, who receive remittances from the United States of America (USA), due to the importance of our country as a recipient of remittances. According to data from the migration and remittances yearbook published in 2017, Mexico ranked fourth in the world for remittances received with $4.8 \%$. Said remittances sent to Mexico reached their historical maximum when reaching 26,970 million dollars in 2016, which represented a growth of $8.8 \%$ at annual rate. At the state level in 2016, 1,463 million dollars entered Puebla and 1,372 million dollars to Guerrero through remittances (Ministry of the Interior, National Population Council, \& BBVA Bancomer Foundation, 2017, p. 124).

The Pew Research Center (2018) stated that the presence of Latin American migrants in the United States is so significant that, together with their descendants born in that country, they constitute the largest minority ethnic group, reaching a figure of 56.5 million people in 2018 (Pew Research Center, 2018, p. 1).

This study is mainly focused on remittances that originate in the United States because it is the country of origin of $94.75 \%$ of remittances that arrive in Mexico, followed by Canada with $1.2 \%$ (Economic Information System, 2017, p. 1). Of the total remittances, most are sent by electronic transfer $(97.8 \%)$ and $64.7 \%$ are paid in Mexico through non-banking institutions (Ministry of the Interior, National Population Council, \& BBVA Bancomer Foundation, 2017, p. 124 ). Among the Mexican migrant population residing in the United States, seven out of ten are economically active and among the activities in which they work in the US, they are mainly construction (17.7\%), hospitality and recreation (15.3\%) and services professionals and administrative (13.0\%) (Ministry of the Interior, National Population Council, \& BBVA Bancomer Foundation, 2017, page 58). In 2016, six out of ten Mexican migrants in the US worked between 35 and 44 hours a week and with this, nearly half of Mexicans had an annual salary between 10 and 30 thousand dollars (Ministry of the Interior, National Population Council, \& BBVA Bancomer Foundation, 2017, page 58).
It is important to carry out a comparative study between the states of Guerrero and Puebla because both have similarities in their rates of migration, marginalization, poverty and social backwardness; according to data from the National Council for the Evaluation of Social Development Policy (2016, p. 10). In this order of ideas, regarding the degree of social backwardness, Guerrero is in second place in the national context and Puebla in fifth place. Regarding the population that is in poverty, the State of Guerrero presents $64.4 \%$. Of this percentage, $41.4 \%$ are in moderate poverty and $23.0 \%$ in extreme poverty. As for Puebla, 59.4\% are in poverty, of which $50.4 \%$ are in moderate poverty and $9.0 \%$ in extreme poverty. This means that more than half of its population is in a situation of poverty (National Population Council, 2010). According to what was indicated by the National Population Council (2010, p. $25)$, Guerrero is one of the entities with a very high degree of marginalization with $19.2 \%$ of the national total. For its part, Puebla is one of the states that is in a high degree of marginalization with $10.9 \%$ compared to the total national population.

The Migration and Remittances Yearbook (2017) specifies that in what refers to returned migrants; Guerrero and Puebla are in fourth and sixth place respectively, which generates a decrease in remittances sent to highintensity migratory towns. Considering these data, it is important to analyze whether migrant families have made investments from remittances during their stay in the US. Likewise, evaluating how they have impacted both the family economy and local development, since the possibility of ceasing to receive remittances is high due to the restrictive policy of the US government (Ministry of the Interior, National Population Council, \& BBVA Bancomer Foundation, 2017, pages 157 and 166).

It should be noted that of the migrants returned in 2015 only $61 \%$ are working as follows: $56 \%$ as employees or workers, $22.2 \%$ as self-employed workers, $8.1 \%$ as day laborers or laborers and $4.3 \%$ as employers or employers. It is noteworthy that only $4.3 \%$ of returned Mexicans generate business and therefore jobs upon their return (Ministry of the Interior, National Population Council, \& BBVA Bancomer Foundation, 2017, page 92). 
A flow of 90 thousand men and 32 thousand women who returned to Mexico was estimated (National Institute of Statistics and Geography \& Secretariat of Labor and Social Welfare, 2016, p. 1).

Derived from the above, this research is organized as follows: The literary review addresses sustainable development, economic sustainability, and sustainability from remittances in Puebla and Guerrero, explains the methodology, and then presents results and conclusions.

\section{Theoretical framework}

\section{a) Sustainable development}

It should be emphasized that the Commission for Environment and Development (WCED) adopted the term "Sustainable Development" as an informative concept in its report Our Common Future (World Commission on Environment and Development, 1987, p. 406).

Meanwhile, Pearce \& Turner (1990) refers to sustainability as "maximizing the net benefits of economic development, subject to maintaining services and the quality of natural resources over time." The concept of sustainable development was described by the World Commission on Environment and Development report, Bruntland, 1987 as "development that meets current needs without compromising the ability of future generations to meet their own needs" (Organization of the United Nations for Education, Science and Culture, 2018, p. 6).

Therefore, sustainable development must keep balance in three basic dimensions: the social, the economic and the ecological or environmental, which would allow to fulfill the ethical and social purpose of development, and with a more efficient disposition and management of resources. , where social planning and the appropriate use of environmental resources would be applied (Haro-Martínez \& Taddei-Bringas, 2014, p. 746). In this order of ideas, sustainability is the ability to achieve sustained economic prosperity over time, while protecting the planet's natural systems and providing a high quality of life for people (Calvente, 2007, p. 3).
In a sense, Van \& Lebel's (2006, p. 448) approach points out that sustainable development is the process of ensuring that all people can achieve their aspirations while maintaining the critical ecological and biophysical conditions that are essential for our collective survival.

Similarly, Prugh, Robert \& Herman (2000, p. 196). They propose a strong democracy based on the premise that the common good is greater than the sum of individual interests. Sustainability can be promoted through broader popular political participation, with dialogue at the community level.

From the above, it follows that sustainability does not only apply to natural resources. For a business to be sustainable it has to be economically sound, otherwise it is impossible to continue operations (Clegg, 2014, p. 15). In the words of Aguilar \& Recaman, (2013, p. 129) the economic dimension of sustainability includes the entire set of human activities related to the production, distribution, consumption of goods and services. By contrast, Clark (1995, p. 227) stated that the evidence around us clearly indicates that people involved in economic development activities at the local, national and global levels are either indifferent or ignorant of the concept of sustainable development.

\section{b) Economic sustainability from remittances}

The concept of sustainability became fashionable in the 1960s due to the rise of environmentalists, who gave priority to caring for the environment (Mokate, 2001).

Importantly, development also became, for a few decades, a hot topic in academic circles around the world: backward countries became underdeveloped, then less developed, and finally developing countries (Sachs, 2009, p. 8). At that starting point, economic growth served as an indicator of development. Then other dimensions were gradually added to the concept, leading to a litany of adjectives: economic, social, cultural, territorial, and, last but not least, political (Sachs, 2009, p. 8). 
It is worth mentioning that the concept of sustainable development described above by the report of the World Commission on Environment and Development; it translates easily into economic terms: an increase in current well-being should not result in a reduction in well-being tomorrow (Barbier, 2016, p. 3). Consequently, today's economic development must ensure that future generations are no worse off than current generations. Or, as some economists put it in a nutshell, per capita welfare should not decline over time (Pezzey, 1989).

For Madero-Gómez \& Zárate-Solís (2016, p. 14), economic sustainability, seen from a business aspect, is directly related to the investment capacity of a country or a certain region in sustainability projects, in addition, economic growth depends largely on it, for this reason it is important to know the strengths and weaknesses it is implying.

Likewise, in the macroeconomic debate, other criteria of economic sustainability are mentioned, such as innovation (Rennings, 2000), competitive advantage (Porter, 2016, p. 20); while criteria such as inflation or trade imbalances are politically important, but they are almost never in the context of sustainability in their broader perspective, as well as the need to balance different interests (Spangenberg, 2005, p. 49).

For his part, Coleman (1990) pointed out that an economic theory capable of addressing the challenge of sustainability must be based on weak comparability and incommensurability, and must overcome logical misperceptions, which result from a fairly static understanding of systems, in place of dynamics.

Interestingly, according to Sudhir \& Amartya (2000) the development process requires an emphasis on what people get from development, not just what they put into it.

For the case that addresses us, economic sustainability is analyzed from the sending of remittances by Mexican migrants from the US to Mexico and the way in which these economic resources are invested.
Thus, remittances have become a flow of foreign currency that has reached a relative importance for the national economy, since it constitutes one of the main items in the line of current transfers in the balance of payments and represents a significant contribution of resources in specific sectors of regional and local economies. (De la Rosa Mendoza, Romero Amayo, \& Pérez Servín, 2006).

Likewise, remittances represent a fairly stable income, unlike the resources received from the sale of oil and foreign direct investment, which have greater variations (De la Rosa Mendoza, Romero Amayo, \& Pérez Servín, 2006). Remittances show a notoriously growing trend and have ended up surpassing income from tourism and agricultural exports (De la Rosa Mendoza, Romero Amayo, \& Pérez Servín, 2006).

Although remittances are not sent for productive investment, they generate a movement in the local economy, first because these family units have a greater consumption of goods such as clothing, food, and the education of children outside the communities; The construction of houses requires materials, labor and services (López-Toxqui, Peña-Olvera, Méndez-Espinoza, Escobedo-Garrido, \& Martínez-Saldaña, 2011).

For this reason, Paulson \& Singer (2000) used information from Mexican migrants residing in the United States to prove that migrants with a greater probability of returning to Mexico save more due to the anticipated future decline in earnings. In fact, they tested the permanent income hypothesis and claim to have found the hypothesis to be valid as long as the migrant is above a "subsistence" threshold (Paulson \& Singer, 2000, p. 5). Likewise, HaroZea (2018, p. 113) found that a third of the remittances sent to the State of Guanajuato were invested in the footwear industry, this confirms that there is an impact on said industry and therefore on local development. of the State.

\section{c) Receipt of remittances in Puebla and Guerrero}

Remittances have a strong impact in the receiving states, as is the case of Puebla and Guerrero, Mexico. 
The migration generated by population flows that move from their country of origin to another in search of better employment opportunities, causes at least two positive externalities in the sending country: it allows an important entry of remittances in favor of ascending and descending relatives of the immigrant, with positive effects on the family microeconomy (increased purchasing power of the beneficiary households); and in the country's macroeconomics (design of productive projects in the expelling communities); and it relaxes the existing pressures in the labor market, by demanding labor that cannot be used in the expelling country due to the precarious economic activity (Reyes Tépach \& Morales Robles, 2015, p. 40).

It should be noted that Puebla has 217 municipalities of which, according to Banco de México data, 90 of them are not remittance recipients. Among the states that received the most remittances in 2017, Puebla is in fifth place with 1,559.28 million dollars. The municipalities with the highest incomes for this concept are Puebla, Atlixco and Tehuacán since they receive 412.10, 124.8, 96.22 million dollars respectively. (Banco de México, Sistema de Información Económica, 2017, p. 1), and has a $3.2 \%$ share in the national Gross Domestic Product (GDP) (National Institute of Statistics and Geography, 2010, p. 1). For his part, Guerrero is in seventh place with $1,424.33$ million dollars received. Among the municipalities with the largest number of remittances received in 2017 are Acapulco de Juárez with 180.08 million dollars, followed by Tlapa de Comonfort with 147.55 million dollars and thirdly Iguala de la Independencia with 118.86 million dollars (Banco de México, Economic Information System, 2017, page 1). While Guerrero has a $1.5 \%$ participation in the national GDP. (National Institute of Statistics and Geography, 2010, p. 1).

Additionally, according to data from the research carried out by López-Toxqui, PeñaOlvera, Méndez-Espinoza, Escobedo-Garrido, and Martínez-Saldaña (2011, p. 207), in the region of Puebla and Veracruz, the needs covered by the Remittances were mainly of the basic type - food and clothing. After covering them, an amount of the remittances was directed to the purchase of land, construction of houses and acquisition of cars.
Shipments are also made in kind, such as clothing, which are not quantified but are important in the social reproduction of family units. It is through remittances in money and shipments in kind that the receiving families have a very important means of subsistence.

Consequently, the impact of income from collective remittances translates into basic infrastructure and service works in the communities of origin of Guerrero, while the impact of family remittances mainly affects the family within the people of Guerrero. For migrants, contributing resources for the benefit of their places of origin demonstrates their love for their land and the desire to maintain ties with their people. Their actions lack double claims (Díaz Garay \& Juárez Gutiérrez, 2006, p. 129).

In sum, once a family begins receiving remittances, they can stop or reduce their work time in Mexico, they do so only to supplement household income, but it depends largely on money sent from the United States. Once remittances begin to flow in significant quantities along with gifts for children to compensate for the absence of the parent or both parents, the family experiences an increase in their standard of living and expectations and gets used to wearing American clothes and shoes that increase spending. So what started as a socially available strategy for family income diversification often ends in permanent or longterm migration, since once the family increases its level of spending it is difficult to return and maintain that standard of living with everyone. family members in Mexico (Castañeda, 2004).

In this regard, a migratory destination that calls the attention of the people of Guerrero is New York and according to (Castañeda, 2004) the migration from Guerrero to New York is seen by the migrants themselves as temporary and basically as an available strategy used by the male heads of families to increase family capital as proposed by the new economic theory of migration. Migrants plan to go to the US for a few years and save money, build a house, buy a taxi, or open a small business. But because their expenses in New York are high, their incomes are relatively low, and since their family depends on their remittances to survive, they have little money to save (Castañeda, 2004). 
In the words of García Gómez, Peláez Herreros, and Fuentes Flores (2015, p. 185), the migratory tradition of a region favors the allocation of a greater proportion of remittances to business investment, for two reasons: the greater age of migrants and the consolidation of institutions. In the case of Mexico, there are businesses as varied as: shoe workshop, shoe factory, jam factory, carpentry, greenhouse, gardening, corner store, tortilla shop, restaurant, party room, aesthetics, among others. By gender, there is a greater tendency for men to own and for women to be lenders. Regarding the place of establishment of the business, those that correspond to owners are located in a much greater proportion in the United States; while those with the participation of partners and, especially, of lenders are located in Mexico. Many choose the option of acting as lenders, since they continue to reside in the United States and are not interested in having their own business in Mexico, since they cannot serve it (García Gómez, Peláez Herreros, \& Fuentes Flores, 2015). Based on the aforementioned concepts, the purpose of this research work is to evaluate whether remittances sent from the United States of America by migrants to their relatives in Mexico, support the economic sustainability of both families and the locality.

\section{Methodology}

This research is quantitative, descriptive, explanatory and transversal. For this research, a sample was selected for convenience to meet certain criteria. The instrument was applied to a non-probability sample by quotas of 50 people, 100 relatives of migrants were surveyed, 50 of them in Puebla, Mexico and 50 in Guerrero, Mexico, who met two criteria, which are: having migrant relatives in United States of America and receive remittances. The data was collected from January 1 to February 28, 2018 directly through a survey. It is important to mention that a form in Google Docs was used for the coding and the SPSS statistics 23 software was used for its analysis. Also, to carry out a more detailed analysis of the investment made in Puebla and Guerrero from remittances, Table 4 is excluding respondents who have received remittances for less than 4 years, assuming that during this time, families prioritize the payment of debts and the payment of basic services, in the same way those who They mentioned that they do not invest, but they do save in the bank.
It is worth mentioning that Puebla receives $5.4 \%$ of remittances from the country and Guerrero receives $5.2 \%$ of remittances from the country (Banco de México, Sistema de Información Económica, 2018, p. 1), which are located within the first ten states with high rates of receipt of remittances. The samples were taken in two states with the objective of evaluating if there are significant differences in the impact of remittances in two states with a migratory tradition and if there is economic sustainability in families from them.

For this research, the destination of remittances was taken into account as the dependent variable, since it is based on this to study the use that is made of the income received by this concept, either for expenditure or investment and as an independent variable, The economic sustainability of migrant families in Puebla and Guerrero is defined, since from this variable we study whether there is sustainable development through the creation of family businesses.

\section{Results}

\section{a) Demographic data of the sample}

$60 \%$ of the total population are women and $40 \%$ are men. $29 \%$ of the people surveyed are in the range of 26 to 35 years, $20 \%$ are between 15 to 25 years, $19 \%$ from 46 to 55 years, $18 \%$ from 36 to 45 years, $10 \%$ from 56 to 65 years and only $4 \%$ of the surveyed population are older than 65 years.

Regarding marital status, married people are the majority within the surveyed community with $35 \%$, followed by people who live in a free union with $29 \%, 23 \%$ are single, in lower percentages are people who were widowed with $6 \%$, those who separated from their partners with $5 \%$ and the divorced with $2 \%$.

It is noteworthy that of the total number of people surveyed, $66 \%$ are heads of the family and $21 \%$ of the sample speak some type of indigenous language and only $47 \%$ of the population can speak and write in Spanish, $49 \%$ report that they know little, and $4 \%$ do not know. 
$31 \%$ of those surveyed have a secondary school, 27\% have a high school education, $18 \%$ have finished primary school, $10 \%$ have a technical education, $7 \%$ have a bachelor's degree and another $7 \%$ have no education at all.

\section{b) Contribution to family income}

In $54 \%$ of households two people contribute, in $30 \%$ only one person contributes, $10 \%$ three people, in $5 \%$ of households four people contribute and in $1 \%$ five people contribute.

\section{c) Economic sustainability from remittances}

Below are the global indicators, that is, they correspond to an average between Puebla and Guerrero.

\section{- Average income in Mexico.}

As for the average income per family member, $25 \%$ said they earn between 300 and 500 pesos a week, $8 \%$ between 501 and 700 , $15 \%$ earn from 701 to 1,000 pesos, $5 \%$ from 1001 to $1500,3 \%$ from 1501 As of $2000,8 \%$ obtained more than 2,000 pesos, and 36\% did not respond.

\section{- Remittances received.}

$20 \%$ say they receive from 1000 to 3000 pesos, $16 \%$ from 3001 to $5000,4 \%$ from 5001 to $7000,16 \%$ from 7001 to $10000,6 \%$ from 10001 to $13000,7 \%$ receive from 13001 to $15000,5 \%$ of 15001 to 18000 another $5 \%$ receive from 18000 to $20,000,1 \%$ receive from 20001 to 23000 , another $1 \%$ from 230001 to 25000 pesos and $3 \%$ receive from 25001 to 30,000 monthly. In these results, it should be noted that $16 \%$ of the surveyed population preferred not to answer this question due to fear or mistrust of the use of information.

\section{- How many benefit}

Overall, $28 \%$ of the surveyed population says that only two people benefit from remittances, $18 \%$ indicate that it benefits three, $12 \%$ one person, $8 \%$ four people, $7 \%$ five people, another $7 \%$ to six people, $6 \%$ to seven, $2 \%$ to eight, $1 \%$ to 12 people and $11 \%$ did not answer the number of beneficiaries. With these results, it can be deduced that most remittances reach small families or that the received transfers do not benefit more people.

\section{Comparative analysis (Puebla vs Guerrero)}

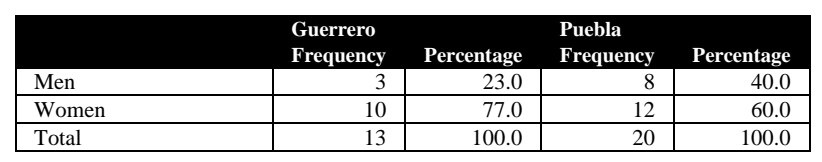

Table 1 Business entrepreneurship by relatives of migrants

Table 1 shows the frequency with which the relatives of migrants carry out ventures, plus the percentage does not refer to the amount invested. Source: self made.

It is worth mentioning that Table 1 shows a notable difference in the state of Guerrero since people who dare to start a business represent $26 \%$ of the population surveyed in Guerrero, who are mostly women with $77 \%$, while that the men who do it represent 23\%. In Puebla $40 \%$ of the surveyed population is an entrepreneur and within these $40 \%$ are men and $60 \%$ women.

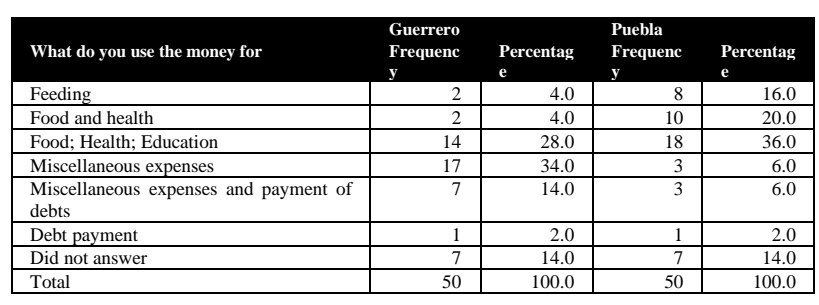

Table 2 Comparison of the expense of remittances

Table 2, represents the way in which the part of remittances that are destined to spending is distributed, since both the respondents in Guerrero and Puebla, have not clearly identified the percentage of remittances that are destined to spending. Source: self made.

In Table 2, we observe that $14 \%$ in Guerrero did not respond and the same percentage did not do so in Puebla, in both states $2 \%$ of the sample used their remittances to pay debts. In Guerrero, $14 \%$ is used for various expenses and debt payments, and in the state of Puebla, 6\% use it in this same area, 34\% in Guerrero and $6 \%$ in Puebla, they use it for various expenses, among which, in addition to food, health and education are transportation, clothing and appliances. For the heading of food, health and education; Guerrero and Puebla allocate $28 \%$ and $36 \%$ respectively. In Guerrero, $4 \%$ use it for food and health, while in Puebla it is $20 \%$. And finally, what is used only for food represents $4 \%$ for Guerrero and 16\% for Puebla. 
In this regard, the migration and remittances yearbook (2016) indicates that the two main reasons why women and men send remittances to Mexico are food, clothing and debt payment. Compared to men, women indicate that a higher percentage of remittances they send goes to health, while men have priority for business and investment. Likewise, in a study carried out in the northern region of the state of Guerrero by (Díaz Garay \& Juárez Gutiérrez, 2006, p. 127) of the total family remittances received, $91 \%$ is destined to the basic needs of the home, food and health , mainly; to a lesser extent, clothing and footwear, as well as home improvement. $4.5 \%$ goes to savings with the idea of spending more in the future and another $4.5 \%$ goes to invest in some business, generally miscellaneous. Regarding the impact that remittances have had on the family economy, $59 \%$ of those surveyed stated that they had improved their quality of life thanks to these incomes, $27.5 \%$ mentioned that very little and $13.5 \%$ said that their standard of living remains the same (Díaz Garay \& Juárez Gutiérrez, 2006, p. 128).

\begin{tabular}{|c|c|c|c|c|}
\hline Assets & $\begin{array}{l}\text { Guerrero } \\
\text { Frequency }\end{array}$ & Percentage & $\begin{array}{l}\text { Puebla } \\
\text { Frequency }\end{array}$ & Percentage \\
\hline Own house & 25 & 50.0 & 18 & 36.0 \\
\hline Own house and automobile & 6 & 12.0 & 16 & 32.0 \\
\hline Car & 1 & 2.0 & 0 & 0.0 \\
\hline Household items & 17 & 34.0 & 16 & 32.0 \\
\hline Did not answer & 1 & 2.0 & 0 & $\begin{array}{l}0.0 \\
\end{array}$ \\
\hline Total & 50 & 100.0 & 50 & 100.0 \\
\hline
\end{tabular}

Table 3 Comparative of the possession of goods

Table 3 represents the assets in which the relatives of migrants who receive remittances have invested in both Guerrero and Puebla, but does not imply an invested percentage. Source: self made

Table 3 shows a comparison of the states of Guerrero and Puebla in terms of possession of material assets, and we find that $50 \%$ of the sample in Guerrero have their own home and in Puebla $36 \%$, complementing this we can note that in Guerrero $12 \%$ have their own house and car, while in Puebla $32 \%$ have it. As for the possession of household appliances, there is no significant difference since in Guerrero they represent 34\% and in Puebla 32\%, 2\% of the Guerrero sample mentioned that they only have a car and another $2 \%$ did not respond.

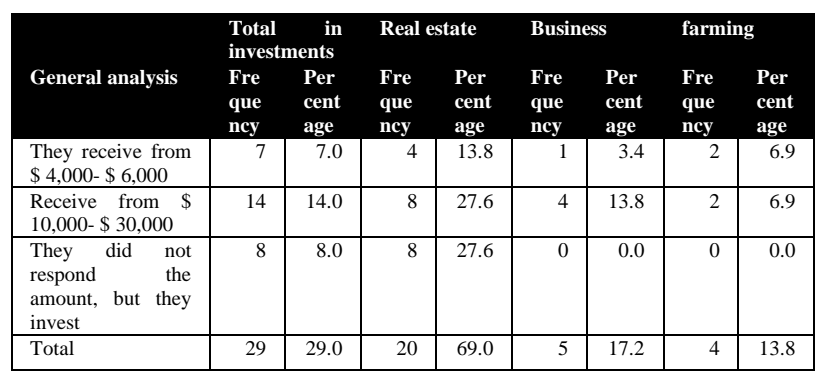

Table 4 Investments based on the amount of remittances received

Table 4 seeks to show how remittance recipients invest, according to the amount received from the United States. Source: self made

Table 4 shows that of the people who receive from $\$ 4000$ to $\$ 6000 ; 13.8 \%$ invest it in real estate, $3.4 \%$ in business and $6.9 \%$ in agriculture. Of those who receive from $\$ 10,000$ to $30,000,27 \%$ invest it in real estate, $13.8 \%$ in business, and $6.9 \%$ in agriculture. $27.6 \%$ of people did not answer the amount they receive, but they did mention that they invest it is in real estate.

Regarding investment, we can see that $29 \%$ of the total surveyed population mentions investing in one of the following items: real estate such as; house room, land or plots; business or agriculture, of this $29 \% ; 16 \%$ correspond to Puebla and $13 \%$ to Guerrero.

\begin{tabular}{|c|c|c|c|c|c|c|c|c|}
\hline \multirow[b]{2}{*}{ Guerrero } & \multicolumn{2}{|c|}{$\begin{array}{l}\text { Total in } \\
\text { investments }\end{array}$} & \multicolumn{2}{|c|}{ Real estate } & \multicolumn{2}{|c|}{ Deal } & \multicolumn{2}{|c|}{ farming } \\
\hline & $\begin{array}{l}\text { Fre } \\
\text { que } \\
\text { ncy }\end{array}$ & $\begin{array}{l}\text { Perc } \\
\text { enta } \\
\text { ge }\end{array}$ & $\begin{array}{l}\text { Fre } \\
\text { que } \\
\text { ncy }\end{array}$ & $\begin{array}{l}\text { Perc } \\
\text { enta } \\
\text { ge }\end{array}$ & $\begin{array}{l}\text { Fre } \\
\text { que } \\
\text { ncy }\end{array}$ & $\begin{array}{l}\text { Perc } \\
\text { enta } \\
\text { ge }\end{array}$ & $\begin{array}{l}\text { Fre } \\
\text { que } \\
\text { ncy }\end{array}$ & $\begin{array}{l}\text { Perc } \\
\text { enta } \\
\text { ge }\end{array}$ \\
\hline $\begin{array}{l}\text { They receive from } \$ \\
4,000-\$ 6,000\end{array}$ & 5 & $\frac{50}{10.0}$ & 4 & 30.8 & 1 & 7.7 & 0 & 0.0 \\
\hline $\begin{array}{l}\text { Receive from } \$ \\
10,000-\$ 30,000\end{array}$ & 1 & 2.0 & 1 & 7.7 & 0 & 0.0 & 0 & 0.0 \\
\hline $\begin{array}{l}\text { They did not } \\
\text { respond the amount, } \\
\text { but they invest }\end{array}$ & 7 & 14.0 & 7 & 53.8 & 0 & 0.0 & 0 & 0.0 \\
\hline Total & 13 & 26.0 & 12 & 92.3 & 1 & 7.7 & 0 & 0.0 \\
\hline
\end{tabular}

Table 5 Diversification of investments in Guerrero

Table 5 seeks to show how remittance recipients in Guerrero invest, according to the amount received from the United States. Source: self made.

Table 5 shows that $26 \%$ of the surveyed population in Guerrero mentioned investing. However, of the total number of respondents who invest, it stands out that nobody does it in the field, regardless of the amount they receive. Recipients of $\$ 4,000$ to $\$ 6,000$ separate their investment in real estate $(30.8 \%)$ and business $(7.7 \%)$.

HARO-ZEA, Karla Liliana \& CONTRERASALCÁNTARA, Karla. Sustainability the remittances received in Puebla and Guerrero, Mexico. Journal of Social Researches. 2020 
Recipients of $\$ 10,000$ to $\$ 30,000$ invest it in real estate and account for $7.7 \%$. In these results, it is highlighted that $53.8 \%$ of those who invest do so in real estate but did not mention the amount of remittances they receive.

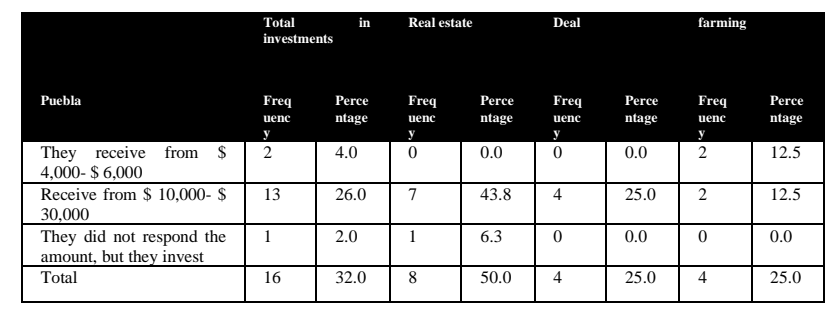

Table 6 Diversification of investments in Puebla

Table 5 seeks to show how remittance recipients in Puebla invest, according to the amount received from the United States. Source: self made

Table 6 details that $32 \%$ of the sample from the state of Puebla invests as follows: those who receive from $\$ 4,000$ to $\$ 6,000$ pesos per month represent $12.5 \%$ of the total and do so only in agriculture. Of those who receive from $\$$ 10,000 to $\$ 30,000,43.8 \%$ invest in real estate, $25 \%$ in business, and $12.5 \%$ in agriculture. Of the people who did not respond to the amount they receive on a monthly basis, $6.3 \%$ reported investing in real estate.

\section{Thanks}

Thanks to the Program for the Professional Development of Teachers (PRODEP) within the framework of the Incorporation of New FullTime Teachers, for financing the field research of this study and for the financial support to the thesis student to promote research in young people.

\section{Conclusions}

The majority of the population receiving remittances only reaches basic levels of education (59\%), and some even have no academic training (7\%), so it can be assumed that the majority did not have opportunities for academic improvement.

Regarding business entrepreneurship by the relatives of migrants, it should be noted that $33 \%$ of them manage to start a business (see Table 1). It highlights that women have more entrepreneurship in both states; Guerrero (60\%) and Puebla (77\%).
In this order of ideas, Puebla is at number 26 and Guerrero at number 32, both in income and expenditure by state with Urban-Rural characteristics (National Institute of Statistics and Geography, 2016).

Regarding the application of remittances destined to spending, it was found that $70 \%$ of the surveyed population in Guerrero use them for basic expenses such as: education, health and food, while in the state of Puebla it occupies 78\% for them. purposes.

Contrary to this, we identify that even though not all remittance beneficiaries tend to invest, there is a higher percentage of investment in Puebla. For these purposes, the majority do so in real estate and others invest both in agriculture and in their own businesses, while Guerrero stands out for the investment in real estate purchases, minimal investment in business and no investment in agriculture, with a total in both states. $29 \%$ (see Table 4).

Well, it is true that the data generated in this research indicates that there is investment in different areas, but it is important to point out that of all the ways in which families usually invest their remittances, the creation of businesses, investment in real estate and agriculture These are the ones that could promote sustainable economic development in the municipalities with high migratory intensity in Puebla and Guerrero (see Table 2 and 4).

On the other hand, remittances sent to families in Puebla and Guerrero, Mexico, represent an outlet for the family economy; however, during the first years of receiving remittances they are used for spending and not for investment, so strategies designed to generate sustainable economic development in Mexico, they must first aim to close the inequality gaps in these states, that is, to positively impact the rates of poverty, extreme poverty and marginalization in which many families currently live in these states. It should be noted that among the main reasons for migration in the states under study are the high rates of poverty and marginalization in the living, Guerrero second place national level and Puebla fifth place nationally (National Population Council, 2010, p. 10). 
Both in the literature review and in the present study, the results point out that migrants in the first years prioritize the payment of debts and cover basic services required by the family and in later years they allocate a part of remittances to investments that In the case of Puebla and Guerrero they are in agriculture, business and mainly in real estate. This is confirmed by Amuedo-Dorantes and Pozo (2002, p. 2), where they point out that remittances can be accumulated and transferred home to invest in physical capital by acquiring assets such as land, capital goods or housing. Alternatively, remittances can represent earnings sent altruistically to cover the daily consumption needs of the sender's home in the home country of origin.

As part of the limitations of the research work, we found the resistance of the respondents to respond and the fear of confidentiality of the data, this derived from the insecurity in the states under study. The aforementioned was more frequent in the state of Guerrero where a large percentage of the population that mentioned investing did not want to reveal the amount of remittances they receive. Also another difficulty encountered was the dialect because in the areas of migratory intensity there are still relatives of migrants who do not speak Spanish but Nahuatl, so they had to work with a translator.

Finally, for Mexican migrants living in the United States, one route to sustainability is the sending of remittances. Therefore, it is possible to affirm that in Puebla and Guerrero, remittances sent by migrants living in the United States to their relatives in Mexico, contribute to sustainability and economic development in states with high migratory intensity. However, it is only possible to see its effects after the families have managed to cover their basic needs and therefore have emerged from the poverty and marginalization that motivated migration.

Finally, it can be said that sustainability has to be a way of life, in such a way that if migrants invest a greater part of remittances and not only $50 \%$ as it turns out in the present study, this would impact more strongly on their quality. of life and opportunities for the next generations. In this regard, Aguilar Sanders \& Recaman Mejía, (2013, p. 128) point out that a sustainable lifestyle is a part of the person's identity, social position, preferences in politics and the psychological demands of people.

\section{References}

Aguilar Sanders, E., \& Recaman Mejía , A. (2013). Innovación, Emprendimiento y Sustentabilidad. México: De La Salle Ediciones

Amuedo-Dorantes, C., \& Pozo, S. (2002). Remittances as Insurance: Evidence from Mexican Migrants. Northeast Universities Development Consortium Conference (pp. 138). Williamstown, Massachusetts: Williams College.

Banco de México. (2017). Sistema de Información Económica. Retrieved from http://www.banxico.org.mx/SieInternet/consult arDirectorioInternetAction.do?accion=consultar Cuadro\&idCuadro $=\mathrm{CE} 166 \&$ locale $=\mathrm{es} \#$

Banco de México. (2018, Mayo 24). Sistema de Información Económica. Retrieved from www.banxico.org.mx/SieInternet/consultarDire ctorioInternetAction.do? accion=consultarCuadr oAnalitico\&idCuadro $=$ CA79\&sector $=1 \&$ locale $=$ es

Barbier, E. B. (2016). Sustainability and Development. Annual Review of Resource Economics, 1-20.

Calvente, A. (2007). El concepto moderno de sustentabilidad. Socioecología y desarrollo sustentable, 1-7.

Castañeda, E. (2004). Transnational Household Economies, Guerrero-New York. Annual Meeting 2005 (pp. 1-20). Philadelphia: American Sociological Association.

Clark, J. (1995). Economic Development vs Sustainable Societies: Reflections on the Players in a Crucial Contest. Annual Reviews Ecol. Syst, 225-248.

Clegg, B. (2014). Negocios Sustentables. México: Trillas.

Coleman, J. S. (1990). Foundations of Social Theory. Cambridge.

Consejo Nacional de Evaluación de la Política de Desarrollo Social. (2016). Porcentaje, número de personas y carencias promedio por indicador de pobreza. México: CONEVAL. 
Consejo Nacional de Población. (2010). Marginación de las localidades. México: CONAPO.

De la Rosa Mendoza, J. R., Romero Amayo, L., \& Pérez Servín , A. (2006). El alcance económico de las remesas en México: consumo de las familias receptoras. El Cotidiano, 76-88.

Díaz Garay, A., \& Juárez Gutiérrez, M. (2006). Migración internacional y remesas: impacto socioeconómico en Guerrero. Papeles de Población, 113-133.

García Gómez, J., Peláez Herreros, O., \& Fuentes Flores, N. (2015). La tradición migratoria como factor explicativo del uso de remesas en la financiación de negocios en Guanajuato. Migraciones Internacionales, 163165.

Haro-Martínez, A., \& Taddei-Bringas, I. (2014). Sustentabilidad y economía: la controversia de la valoración ambiental. Economía, Sociedad y Territorio, 743-767.

Haro-Zea, K. L. (2018). Impact of migrant remittances on the footwear industry in Guanajuato. Global Journal of Business Research, 105-114.

Instituto Nacional de Estadística y Geografía \& Secretaría del Trabajo y Previsión Social. (2016). Encuesta Nacional de Ocupación y Empleo. Ciudad de México: INEGI.

Instituto Nacional de Estadística y Geografía. (2010, 01 01). Cuéntame... de México. Retrieved $01 \quad 18, \quad 2018, \quad$ from http://cuentame.inegi.org.mx/monografias/infor macion/pue/poblacion/m_migratorios.aspx?tem $\mathrm{a}=\mathrm{me} \& \mathrm{e}=21$

Instituto Nacional de Estádística y Geografía. (2016). Encuesta Nacional de Ingresos y Gastos de los Hogares. México: INEGI.

López-Toxqui, M., Peña-Olvera, B., MéndezEspinoza, J., Escobedo-Garrido, J., \& MartínezSaldaña, T. (2011). Migración y remesas: aporte al desarrollo local en regiones de Puebla y Veracurz, México. Agricultura, Sociedad y Desarrollo, 193-208.
Madero-Gómez, S. M., \& Zárate-Solís, I. A. (2016). La sostenibilidad desde una perspectiva de las áreas de negocios. Cuadernos de Administración, 7-19.

Mokate, K. M. (2001). Eficacia, eficiencia, equidad y sostenibilidad: ¿Qué queremos decir? Banco Interamericano de Desarrollo - Serie de documentos de trabajo I-24, 41-45.

Organización de las Naciones Unidas para la Educación, la Ciencia y la Cultura. (2018). Educación para el Desarrollo Sostenible. Paris, Francia: UNESCO.

Paulson, A., \& Singer, A. (2000). Savings and Settlement: Evidence from Mexican Migrants. Citado por Amuedo-Dorantes \& Pozo (2002) Remittances as Insurance: Evidence from Mexican Migrants, 5.

Pearce, D. W., \& Turner, R. K. (1990). Economics of natural resources and the environment. JHU Press.

Pew Research Center. (2018, 06 14). Pew Research Center. Retrieved from http://www.pewhispanic.org/2017/09/18/factson-u-s-latinos/

Pezzey, J. (1989). Economic analysis of sustainable growth and sustainable development. Washington D.C.: World Bank. Environ. Dep. Work.

Porter, M. E. (2016). Ventaja Competitiva. México: Patria.

Prugh, T., Robert, C., \& Herman, D. (2000). The Local Politics of Global Sustainability. Washington, D.C: Island Press.

Rennings, K. (2000). Redefining innovationeco-innovation research and the contribution from ecological economics. Ecological Economics, 319-332.

Reyes Tépach, M., \& Morales Robles, A. (2015). El flujo migratorio internacional de México hacia los Estados Unidos y la captación interna de las remesas familiares, 2000-2015. México: SEDIA.

Sachs, I. (2009). Revisiting Development in the Twenty-First Century. International Journal of Political Economy, 5-21. 
Secretaría de Gobernación, Consejo Nacional de Población, \& Fundación BBVA Bancomer. (2017). Anuario de Migración y Remesas. México: BBVA.

Sistema de Información Económica. (2017). País de origen de los ingresos por remesas. México: Banco de México.

Spangenberg, J. H. (2005). Economic sustainability of the economy: Concepts and indicators. International Journal of Sustainable Development, 47-64.

Sudhir, A., \& Amartya, S. (2000). The Income Component of the Human Development Index. Journal of Human Development, 1-24.

Van Kerkhoff, L., \& Lebel, L. (2006). Linking Knowledge and Action for Sustainable Development. Annu. Rev. Environ. Resour, 445477.

World Commission on Environment and Development. (1987). Our Common Future. Our Common Future (p. 404). New York: Oxford Univ. Press. 